\title{
ЕКОНОМІКА
}

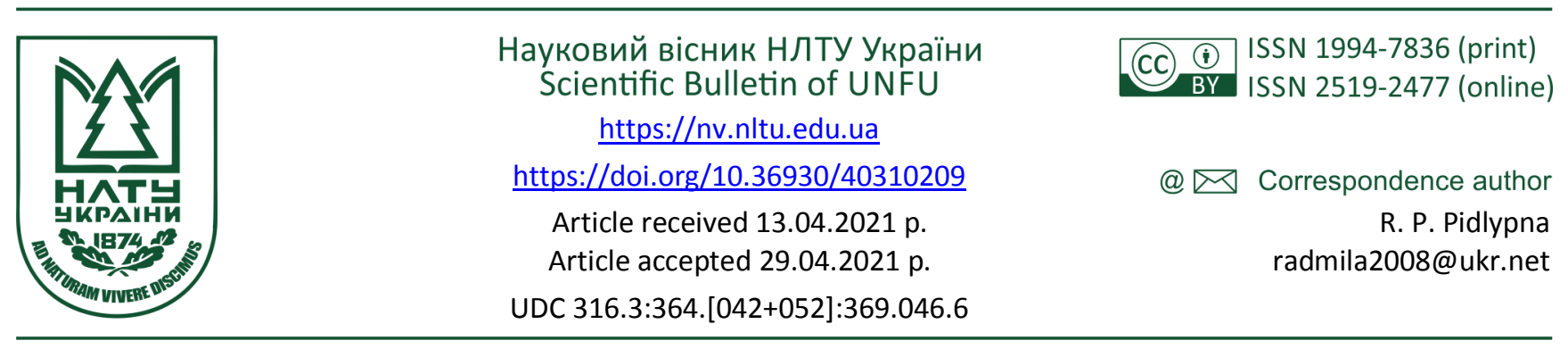

Р. П. Підлипна

Ужгородський торговельно-економічний інститут Київського НТЕУ, м. Ужгород, Украӥна

\section{ЗАГОСТРЕННЯ СОЦІАЛЬНИХ РИЗИКІВ В УКРАЇНІ В КОНТЕКСТІ ПАНДЕМІЇ COVID-19}

Систематизовано передумови виникнення соціальних ризиків в Україні, охарактеризовано основні проблеми перерозподілу ресурсів. Показано, що недостатність нормативно-правового регулювання якості надання соціальних послуг ускладнює контроль за ефективністю видатків на соціальні заходи. Виявлено, що нестабільність економічної ситуації в Україні, підсилена впливом пандемії Covid-19, призвела до зростання ризиків смерті значної частини українських громадян, інвалідізації чи довготривалої втрати працездатності, значного зростання матеріальних затрат на лікування, зростання рівня безробіття (у т.ч. прихованого) та погіршення соціально-економічного забезпечення працівників. Проаналізовано загальну і структурну динаміку видатків Державного бюджету, відзначено зростання видатків на соціальний захист населення та охорону здоров'я. Показано, що аналогічна тенденція структурної динаміки витрат соціального спрямування зумовлена намаганням інституційної підтримки населення в умовах пандемії. Водночас, виявлено зміни в програмах соціального захисту населення, які свідчать про зменшення фінансування окремих соціальних програм та додаткову бюджетну підтримку Пенсійного фонду України. Критично проаналізовано доцільність витрат коштів Фонду боротьби з Covid-19, виявлено понад 37 \% нецільового спрямування коштів. 3 огляду на загрозливу динаміку третьої хвилі пандемії, що проявилась стрімким зростанням добової кількості інфікованих і померлих внаслідок захворювання Covid-19 та тенденцією до зменшення віку нових хворих, досліджено можливості і перспективи імунізації населення як основного інструменту боротьби із пандемією, доведено, що недостатність коштів можна було компенсувати шляхом ефективнішого спрямування витрат Фонду. Окреслено інші соціальні ризики, зокрема проаналізовано тенденції зростання безробіття в умовах карантинних обмежень.

Ключові слова: смерть; інвалідізація; втрата працездатності; безробіття; видатки Державного бюджету.

\section{Вступ}

Прогалини у системі соціального захисту України, неузгодженість між завданнями і цілями соціальної та економічної політики держави призводять до виникнення соціальних ризиків. Нестабільність економічної ситуації в Україні, підсилена впливом глобальної фінансово-економічної і соціальної кризи, зумовленої пандемією Covid-19, призвела до зростання ризиків безробіття, знецінення доходів, i, як наслідок - до зниження рівня життя населення. Недосконалість вітчизняної системи охорони здоров'я, технологічне відставання економічної системи, зменшення можливостей трудової мобільності, погіршення якості навчання зумовлюють соціально-економічну нерівність у суспільстві через безпрецедентне скорочення економічної діяльності, виникнення ризиків для життя і здоров'я громадян, зростання рівня безробіття. Відповідно, актуалізуються питання ідентифікації найбільших ризиків, пов'язаних із соціально-економічними обмеженнями, спричиненими пандемією, які можуть призвести до непоправних наслідків та втрати соціальних можливостей для значної частини населення.
Об'єкт дослідження - соціальні ризики.

Предмет дослідження - інституційні інструменти реалізації програм соціального захисту, що дасть змогу провести критичний аналіз прогалин інституційного характеру.

Мета роботи - дослідження основних соціальних ризиків для українського суспільства, зумовлених стрімким поширенням пандеміï Covid-19, які потребують термінового регулювання шляхом запровадження інституційних можливостей фінансової компенсації соціальних ризиків.

Для досягнення зазначеної мети визначено такі основні завдання дослідження: систематизувати передумови виникнення соціальних ризиків в Україні; проаналізувати загальну та структурну динаміку видатків Державного бюджету; виявити зміни в програмах соціального захисту населення; проаналізувати доцільність витрат коштів Фонду боротьби з Covid-19; дослідити перспективи імунізації як основного інструменту боротьби із пандемією, окреслити інші соціальні ризики.

Наукова новизна отриманих результатів дослідження - вперше на підставі системного дослідження видатків бюджету на соціальний захист запропоновано кри-

Інформація про авторів:

Підлипна Радміла Петрівна, д-р екон. наук, доцент, кафедра фінансів. Email: radmila2008@ukr.net; https://orcid.org/0000-0001-6886-5834

Цитування за ДСТУ: Підлипна Р. П. Загострення соціальних ризиків в Україні в контексті пандемії COVID-19. Науковий вісник НЛтУ України. 2021, т. 31, № 2. С. 57-62.

Citation APA: Pidlypna, R. P. (2021). Exacerbation of social risks in Ukraine in the context of the COVID-19 pandemic. Scientific Bulletin of UNFU, 31(2), 57-62. https://doi.org/10.36930/40310209 
тичний аналіз прогалин інституційного характеру.

Практична значущість результатів дослідження окреслено видатки бюджету на соціальний захист, які потребують термінового регулювання, оглянуто інституційні можливості фінансової компенсації соціальних ризиків.

Аналіз останніх досліджень та публікацій. У сучасних дослідженнях приділяють увагу аналізу різних тенденцій розвитку систем соціального захисту населення. Зокрема, О. Шевченко та ін., аналізуючи забезпечення рівноваги між соціальними цілями суспільства і ринком, відзначають розвиток інститутів соціального партнерства і соціальної інклюзії [4]. І. Пелішенко приходить до висновку про зростання кількості особистісних соціальних орієнтирів. Водночас, тотальна нестабільність і невизначеність спричиняє до виникнення нових, складно прогнозованих соціальних ризиків [11]. А. Бойко та В. Боженко проаналізували вплив системних ризиків у контексті суспільних, економічних і політичних загроз, запропонувавши економіко-математичну модель оцінювання такого впливу [2].

I. Міхно та ін. визначають стратегічну мету політики у сфері соціальної безпеки як збереження сталого розвитку і підвищення якості життя громадян. Автори наголошують, що управління соціальними ризиками має бути комплексним [1]. В. Єлісєєв та ін. зазначають, що ефективна стратегія управління соціальними ризиками надзвичайних ситуацій $є$ передумовою якісного функціонування державної системи цивільного захисту [10]. Для розуміння можливого виникнення соціальних ризиків особливе значення має дослідження Т. Васильєвої та С. Лєонова, які проаналізували макроекономічні та соціальні наслідки епідемій останнього десятиріччя у національному, світовому та регіональному контекстах [5]. Також значний аналітичний матеріал наведено в роботі М. Сидоркіної, яка вивчала громадянські компетентності, необхідні для подолання загроз і викликів, породжених пандемією та низьким рівнем згуртованості суспільства [6].

Стрімке поширення вірусу, ризики надмірного навантаження на систему охорони здоров'я, недостатність матеріально-технічного забезпечення соціальної системи вимагають оновлення політики соціальних видатків держави. Так, І. Свидрук, узагальнивши дослідження особливостей функціонування в умовах виходу із соціально-економічної кризи, зумовленою пандемічними обмеженнями, стверджує, що відновлення ефективної діяльності суб'єктів господарювання має відбуватись керовано, цілеспрямованою дією всіх учасників управління із необхідною імплементацією креативних технологій в управлінські алгоритми на усіх стадіях виходу з кризи [12]. Важливі ініціативи у цьому напрямку пропонують Л. Лисяк та інші, зокрема щодо планування та прозорості соціальних видатків бюджету, зміцнення інституту громадського контролю та звітності [16]. Більшість зарубіжних досліджень, пов'язаних з проблемами соціальних ризиків внаслідок стрімкого поширення пандемії, мають вузькоспеціалізовану спрямованість щодо економічних наслідків, підтримки медичного персоналу та згуртованості в суспільстві. Водночас, деякі дослідження все ж наближають нас до розуміння національних політик щодо соціальної підтримки населення $[3,17]$ або розвитку корпоративної соціальної відповідальності [9].

\section{Результати дослідження та їх обговорення}

У звіті World Economic Forum 2021 р. найвірогіднішими соціальними ризиками ближчого десятиліття експерти називають проблеми, пов'язані з екологічними проблемами та інфекційними хворобами [13]. Саме із цими ризиками пов'язані критичні прогнози щодо економічної стагнації та спричинених нею глобальної кризи зайнятості і відповідного скорочення засобів до існування у значних прошарках світових спільнот.

Передумовою виникнення соціальних ризиків в Україні $є$ неузгодженість між соціальною та економічною політикою. Загалом соціальній сфері в Україні притаманна непрозора система надання соціальних пільг, що не сприяє ефективному перерозподілу ресурсів для надання допомоги малозабезпеченим верствам населення. Недостатність нормативно-правового регулювання якості надання соціальних послуг ускладнює контроль за ефективністю видатків на соціальні заходи. Водночас, недофінансування соціальної сфери, покриття тільки поточних видатків призвело до фактичного руйнування соціальної інфраструктури, морального та фізичного зносу основних засобів, хронічної потреби у капітальних видатках. Така ситуація спричиняє до зниження якості надання соціальних послуг, зростання навантаження на бюджети різних рівнів, а хронічна дефіцитність бюджетів зумовлює фінансування цього сегменту за залишковим принципом. Отож, пандемія Covid-19 тільки посилила вплив описаних чинників на систему соціального забезпечення в Україні (табл. 1), загостривши наявні у ній ризики і спричинивши до різкого зростання видатків бюджету на охорону здоров'я і соціальний захист населення (рис. 1).

Табл. 1. Основні зміни у програмах соціального захисту населення у Державному бюджеті України на 2020 р. (млн грн)

\begin{tabular}{|l|c|c|c|}
\hline \multicolumn{1}{|c|}{ Програма } & $\begin{array}{c}\text { Запла- } \\
\text { новано }\end{array}$ & $\begin{array}{c}\text { Виділе- } \\
\text { но }\end{array}$ & $\begin{array}{c}\text { 3міна } \\
\text { видат- } \\
\text { ків, } \%\end{array}$ \\
\hline $\begin{array}{l}\text { Субсидії громадянам на оплату жит- } \\
\text { лово-комунальних послуг у грошо- } \\
\text { вій формі }\end{array}$ & 47570 & 39329,5 & $-17,3$ \\
\hline $\begin{array}{l}\text { Забезпечення виплати пенсій (у т.ч. } \\
\text { надбавок) та покриття дефіциту Пен- } \\
\text { сійного фонду України }\end{array}$ & 172576 & 202280,4 & $+17,2$ \\
\hline $\begin{array}{l}\text { Заходи із соціальної, трудової і про- } \\
\text { фесійної реабілітації осіб з інвалід- } \\
\text { ністю }\end{array}$ & 1532,6 & 1195,6 & $-22,0$ \\
\hline $\begin{array}{l}\text { Компенсація частини витрат на ре- } \\
\text { алізацію програм соціального захис- } \\
\text { ту населення }\end{array}$ & 150 & 10 & $-93,3$ \\
\hline $\begin{array}{l}\text { Пілотний проект "Розвиток соціаль- } \\
\text { них послуг" }\end{array}$ & 100 & 10 & $-90,0$ \\
\hline $\begin{array}{l}\text { Підвищення кваліфікації працівни- } \\
\text { ків системи соціального захисту на- } \\
\text { селення }\end{array}$ & 0,7 & 0 & $-100,0$ \\
\hline
\end{tabular}

Загалом частка видатків бюджету на соціальний захист населення зросла у 2020 р. до 25,1 \% (у 2018 р. вона становила 16,6 \%), частка видатків на охорону здоров'я - до 9,7 \% (у 2018 р. - 2,3\%). Розглядаючи структурну динаміку витрат соціального спрямування, можна побачити аналогічну тенденцію зростання, зумовлену насамперед намаганням інституційної підтримки населення в умовах пандемії (рис. 2).

Водночас, детальний аналіз змін до Державного бюджету 2020 р. [8] щодо соціального захисту населення (табл. 1) свідчить про згортання або істотне зменшення фінансування окремих соціально значущих програм. 


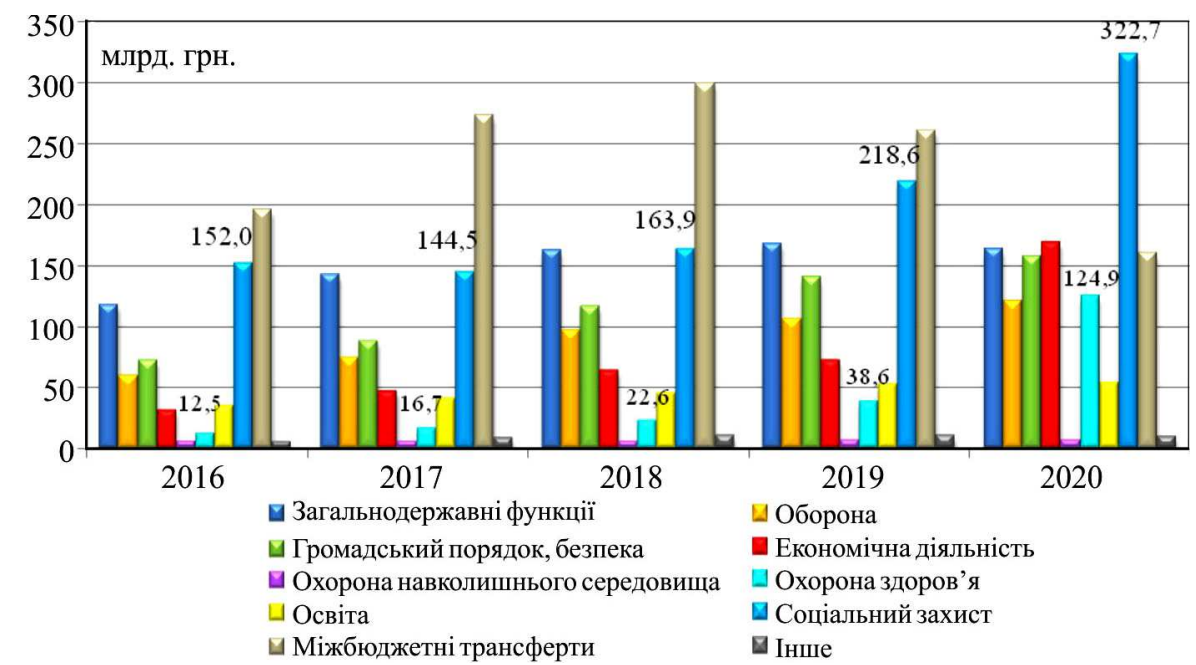

Рис. 1. Динаміка видатків державного бюджету України у 2016-2020 pр. Розраховано за даними [15]

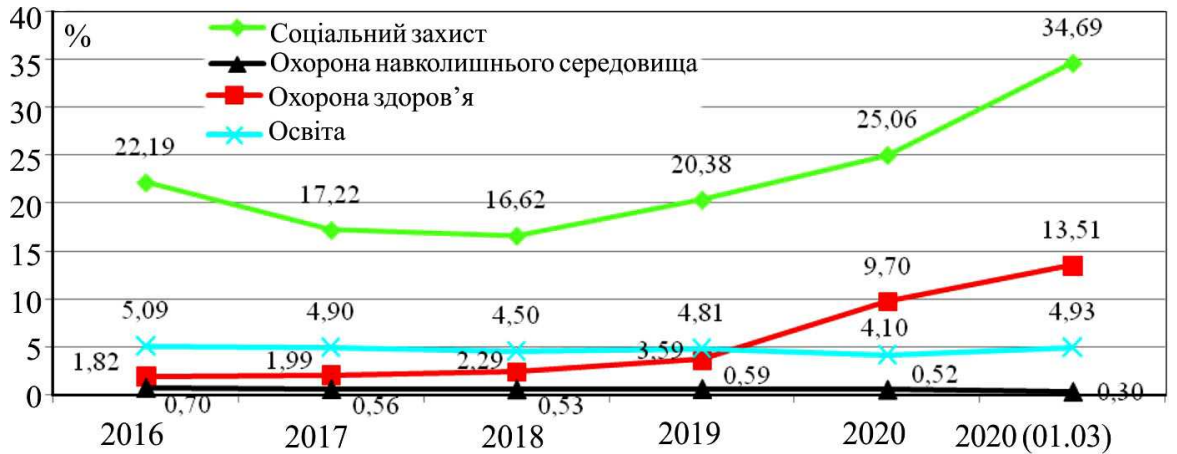

Рис. 2. Структурна динаміка видатків державного бюджету України соціального спрямування у 2016-2021 рр. Розраховано за даними [15]

Отож, попри декларацію соціальної підтримки найбільш незахищених верств населення під час пандемії, видатки на виплату пільг і житлових субсидій Кабінет Міністрів України у 2020 р. скоротив на 8,2 млрд грн, підвищивши, окрім цього, соціальні нормативи для розрахунку субсидій. У Бюджеті України на 2020 р. планувалась програма підтримки 50 об'єднаних територіальних громад (по 2 млн грн для кожної) для розвитку соціальних послуг, зокрема денного догляду за дітьми 3 інвалідністю, забезпечення інклюзивного навчання i підтримувального проживання. Як бачимо, внаслідок пандемії цю програму практично згорнуто. Загалом заплановані видатки соціального спрямування скоротились на 9,8 млрд грн (8,3 \%), водночас, бюджетна підтримка Пенсійного фонду збільшилась на 29,7 млрд грн $(17,2 \%)$.

Обговорення результатів досліджсення. Основними соціальними ризиками, пов'язаним 3 пандемією, є смерть значної частини українських громадян, інвалідізація чи довготривала втрата працездатності, значні матеріальні затрати населення і громад на лікування і постковідне відновлення. На момент написання цієї статті кількість підтверджених випадків захворювання на Соvid-19 в Україні сягнула понад 1646 тис. осіб, з них майже 32 тис. (1,94 \%) померло. Динаміка третьої хвилі захворювання $\epsilon$ надзвичайно загрозливою: знижується середньодобова кількість осіб, що одужують, катастрофічно зростає добова кількість інфікованих (з подвоєнням кількості кожні 15-20 днів) і померлих внаслідок захворювання Covid-19. Окрім цього, намітилась тенденція до зменшення віку нових хворих (за рахунок скорочення частки хворих старших 60 років і збільшен- ня частки неповнолітніх хворих). Іншими соціальними ризиками є зростання безробіття (у т.ч. через карантинні заходи та/або тимчасову заборону певних видів діяльності), зменшення реальних доходів населення, зростання панічних настроїв у суспільстві.

У березні 2020 р. шляхом внесення змін до Державного бюджету України було створено Фонд боротьби 3 гострою респіраторною хворобою Covid-19 у розмірі 64,7 млрд грн [8]. Кошти передбачалось спрямовувати на локалізацію та ліквідацію спалахів пандемії, закупівлю медичних послуг за програмою державних гарантій; доплати медикам та іншим категоріям працівників, які забезпечують життєдіяльність населення; грошову допомогу громадянам; надання трансфертів Пенсійному фонду України, Фонду соціального страхування України і Фонду загальнообов'язкового державного соціального страхування України на випадок безробіття. Однак детальний аналіз виділення і використання коштів Фонду (табл. 2) свідчить про наявність і фінансування бюджетних програм, які навіть опосередковано не є дотичними до соціального забезпечення різних категорій громадян у зв'язку з пандемією.

Зокрема, Міністерству юстиції на виконання рішень щодо справ проти України виділено 103 млн грн (0,14 \% сукупних видатків Фонду), Державне агентство автомобільних доріг України отримало 26,2 млрд грн для розвитку мережі та утримання автомобільних доріг загального користування (36,36 \%), у Міністерство молоді та спорту надійшло 88,3 млн грн. для розвитку спорту серед осіб з інвалідністю $(0,12 \%)$ та 387,5 млн грн - для розвитку спорту вищих досягнень та резервного спорту $(0,54 \%)$. 
Табл. 2. Розподіл бюджетних коштів, спрямованих у Фонд боротьби з Covid-19 у 2020 р. (на кінець року)

\begin{tabular}{|c|c|c|c|c|}
\hline \multirow{2}{*}{$\begin{array}{l}\text { № } \\
3 / \Pi\end{array}$} & \multirow{2}{*}{$\begin{array}{c}\text { Головний розпорядник коштів/Назва бюджетної програми } \\
\text { Джерело: сформовано за даними [8]. }\end{array}$} & \multirow{2}{*}{$\begin{array}{c}\text { Обсяг коштів, } \\
\text { тис. грн }\end{array}$} & \multicolumn{2}{|c|}{ Обсяг виконання } \\
\hline & & & тис. грн & $\%$ \\
\hline 1 & Міністерство соціальної політики, всього & 6759786,0 & 4044278,6 & 59,8 \\
\hline 1.1 & Виплата допомоги на дітей ФОП I та II груп & 1369301,7 & 1271910,2 & 92,9 \\
\hline 1.2 & Фінансова допомога для страхових виплат на безповоротній основі & 107211,0 & 92736,3 & 86,5 \\
\hline 1.3 & Фінансова допомога для виплати матеріального забезпечення на поворотній основі & 1807700,0 & 1807695,4 & 100,0 \\
\hline 1.4 & Страхові виплати медичним працівникам та членам їхніх сімей & 233322,0 & 62744,7 & 26,9 \\
\hline 1.5 & $\begin{array}{l}\text { КПКВК } 2501170 \text { Надання одноразової допомоги застрахованим особам, які можуть } \\
\text { втратити доходи через повну заборону сфери їх діяльності }\end{array}$ & 3242251,3 & 809192,0 & 25,0 \\
\hline 2 & Міністерство розвитку економіки, торгівлі та сільського господарства, всього & 10681590,3 & 8774816,7 & 82,1 \\
\hline 2.1 & Виплати по частковому безробіттю & 2803000,0 & 2780408,1 & 99,2 \\
\hline 2.2 & Фінансова допомога на поворотній основі & 1277000,0 & 1277000,0 & 100,0 \\
\hline 2.3 & Забезпечення виплати допомоги по безробіттю & 4171228,3 & 3865852,6 & 92,7 \\
\hline 2.4 & $\begin{array}{l}\text { Одноразова компенсація суб'єктам господарювання (юридичним особам) для відшко- } \\
\text { дування витрат на ЄСВ }\end{array}$ & 630362,0 & 204596,4 & 32,5 \\
\hline 2.5 & Одноразова допомога суб'єктам господарювання & 1800000,0 & 646959,6 & 35,9 \\
\hline 3 & Міністерство охорони здоров'я, всього & 20468596,6 & 17776081,6 & 86,8 \\
\hline 3.1 & Придбання апаратів штучної вентиляції легень & 100000,0 & 84000,0 & 84,0 \\
\hline 3.2 & $\begin{array}{l}\text { Забезпечення готовності системи громадського здоров'я на спалахи Covid-19, забезпечен- } \\
\text { ня засобами індивідуального захисту працівників закладів екстреної медичної допомоги }\end{array}$ & 3979992,3 & 3288630,3 & 82,6 \\
\hline 3.3 & Придбання обладнання для приймальних відділень опорних закладів охорони здоров'я & 2302620,0 & 2302620,0 & 100,0 \\
\hline 3.4 & $\begin{array}{l}\text { працівникам закладів охорони здоров'я, які на- } \\
\text { vid-19 }\end{array}$ & 5539316,4 & 5307744,6 & 95,8 \\
\hline 3.5 & $\begin{array}{l}\text { б бюджету місцевим бюджетам на здійснення доплат працівни- } \\
\text { доров'я }\end{array}$ & 416043,9 & 169096,6 & 40,6 \\
\hline 3.6 & $\begin{array}{l}\text { Субвенція з державного бюджету місцевим бюджетам на забезпечення ліжкового фон- } \\
\text { ду подачею кисню }\end{array}$ & 1466613,3 & 1419309,1 & 96,8 \\
\hline 3.7 & $\begin{array}{l}\text { Субвенція з державного бюджету місцевим бюджетам на запобігання, локалізацію та } \\
\text { ліквідацію спалахів Covid-19 }\end{array}$ & 259 & 231212,5 & 89,2 \\
\hline 3.8 & $\begin{array}{l}\text { Субвенція з державного бюджету місцевим бюджетам на облаштування тимчасових } \\
\text { закладів охорони здоров'я }\end{array}$ & 90249,0 & 50388,3 & 55,8 \\
\hline 3.9 & гарантій медичного обслуговув & 7 &, 1 & 74,1 \\
\hline 3.10 & $\begin{array}{l}\text { Субвенція з державного бюджету місцевим бюджетам для забезпечення опорних зак- } \\
\text { ладів охорони здоров'я системами рентгенівськими та апаратами ультразвукової діаг- } \\
\text { ностики }\end{array}$ & 1049650,0 & 1021174,1 & 97,3 \\
\hline 4 & Міністерство розвитку громад та територій & 1680000,0 & 1381587,5 & 82,2 \\
\hline 4.1 & $\begin{array}{l}\text { Субвенції на реалізацію проектів з капітального ремонту прийма } \\
\text { опорних закладах охорони здоров'я }\end{array}$ & 168 & 3,5 & 82,2 \\
\hline 5 & Державне управління справами & 51215,2 & 51135,2 & 99,8 \\
\hline 5.1 & 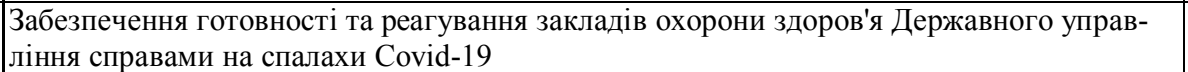 & 51215,2 & 51135,2 & 99,8 \\
\hline 6 & Мiнiс & 126680,1 & 123845,5 & 97,8 \\
\hline 6.1 & $\begin{array}{l}\text { Забезпечення готовнс } \\
\text { Державної криміналь }\end{array}$ & 22572,8 & 22260,0 & 98,6 \\
\hline 6.2 & $\begin{array}{l}\text { Забезпечення засобами індивідуального захисту педагогічних та науково-педагогічних } \\
\text { працівників навчальних закладів Державної кримінально-виконавчої служби України } \\
\text { та здобувачів освіти }\end{array}$ & 1107,3 & 860,6 & 77,7 \\
\hline 6.3 & $\begin{array}{l}\text { Платежі на виконання рішень закордонних юрисдикційних органів, прийнятих за нас- } \\
\text { лідками розгляду справ проти України }\end{array}$ & 103000,0 & 100724,9 & 97,8 \\
\hline 7 & Міністерство внутрішніх справ & 4708474,3 & 4702453,4 & 99,9 \\
\hline 7.1 & Здійснення доплати особам, зайнят & 193274,2 & 193169,5 & 99,9 \\
\hline 7.2 & Здійснення доплат & 4228919,0 & 4228700,1 & 100,0 \\
\hline 7.3 & Здійснення доплати військов & 103774,7 & 103560,9 & 99,8 \\
\hline 7.4 & Здійснення доплати військовослужбовцям Національної гвардії & 125105,5 & 125103,9 & 100,0 \\
\hline 7.5 & Здійснення працівникам, безпосередньо зайнятим на роботах з ліквідації захворюва & 29109,9 & 29102,4 & 100,0 \\
\hline 7.6 & Облаштування мобільного госпіталю Державної служби з надзвичайних ситуацій & 28291,0 & 22816,6 & 80,6 \\
\hline 8 & ріг України & 26182997,4 & 25726813,2 & 98,3 \\
\hline 8.1 & Розвиток мережі та утримання автомобільних доріг & 26182997,4 & 25726813,2 & 98,3 \\
\hline 9 & Міністерство культури та інформаційної політики & 777778,0 & 680502,7 & 87,5 \\
\hline 9.1 & Державна підтримка сфери культури, туризму та креативних індустрій & 777778,0 & 680502,7 & 87,5 \\
\hline 10 & Міністерство освіти і науки & 52450,0 & 41907,0 & 79,9 \\
\hline 10.1 & Повернення коштів, сплачених за надання послуги із проведення пробного ЗНО у $2020 \mathrm{p}$ & 52450,0 & 41907,0 & 79,9 \\
\hline 11 & Міністерство молоді та спорту & 475799,9 & 409581,0 & 86,1 \\
\hline 11.1 & Розвиток спорту серед осіб з інвалідністю & 88323,6 & 82926,4 & 93,9 \\
\hline 11.2 & Розвиток фізичної культури, спорту вищих досягнень та резервного спорту & 387476,30 & 326654,60 & 84,3 \\
\hline 12 & Фонд держмайна & 48400,0 & 14553,7 & 30,1 \\
\hline 12.1 & Заходи, пов'язані з проведенням приватизації державного майна & 48400,0 & 14553,7 & 30,1 \\
\hline & Разом & 72013767,82 & 63727556,1 & $\mathbf{8 8 , 5}$ \\
\hline
\end{tabular}


Водночас, Фонд держмайна отримав 48,4 млн грн для реалізації заходів, пов'язаних з проведенням приватизації державного майна $(0,07 \%)$. Отже, нецільове спрямування коштів становило 26810,2 млн грн або $37,23 \%$ сукупних видатків Фонду.

Окрім цього, незважаючи на виголошення вищим керівництвом держави намірів про створення власної та бронювання вакцин на світовому фармацевтичному ринку, у бюджеті Фонду не було закладено відповідних коштів. Більше того, анонсування розробки вакцини вітчизняного виробництва, хоча і супроводжувалось гучними заявами про обнадійливі результати доклінічної фази випробовувань, однак не містили ані назви наукової установи-розробника, ані навіть приблизних термінів готовності препарату. Відтак єдиним шляхом імунізації населення на сьогодні залишається закупівля імпортних препаратів, а зважаючи на темпи проведення вакцинації, відсутність законтрактованих обсягів і надзвичайний попит, широкий доступ до вакцин українські громадяни отримають не раніше 2022 року [13].

На сьогодні у світі використовують 10 вакцин, попри те, що досі не завершені дослідження щодо їх безпеки, ефективності та тривалості імунного захисту, отож, більшість 3 них схвалена ВОО3 для використання в надзвичайних ситуаціях. Вартість препаратів не тільки різниться залежно від виробника, але i диференціюється залежно від постачання на внутрішній чи зовнішній ринки. Так, вартість препарату Moderna (США) становить 25-37 дол. США за дозу, Johnson \& Johnson (США) - 10 дол. США, Pfizer (США, Німеччин $a)$ - 1619,5 дол. США, Sinovac (Китай) - 13,7-19,7 дол. США (угода з Україною передбачає ціну 18 доларів США),
Covaxin (Індія) - 3-10 дол. США, Covishield (Індія) - 311 дол. США (через непрозорість договорів вартість поставок цієї вакцини в Україну залишається невідомою), AstraZeneca (Британія та Швеція) - 4-5 дол. США, Супутник V (Росія) - 8-10 дол. США. Отож, розрахункова вартість суцільної імунізації населення України (на 01.02.2021 р. - 41554,8 тис. осіб [7]) при офіційному курсі 28,13 грн за 1 долар США (станом на ту ж дату) коливається в межах 5,8 млрд грн (AstraZeneca) - 43,3 млрд грн (Moderna), що становить від 21,8 до 161,4 \% (за умови закупівлі найдорожчої вакцини на ринку) нецільового спрямування коштів Фонду боротьби з Covid-19. Натомість Міністерство охорони здоров'я України оприлюднило наміри охопити безкоштовною вакцинацією $20 \%$ населення у 2021 р. (медиків, учасників ООС, громадян віком 60 років і старше, співробітників структур держбезпеки, працівників освіти, а починаючи 3 листопада - інших категорій населення).

Істотних соціальних ризиків зазнають і громадяни, які залишились поза увагою програм соціального захисту. Зокрема, карантинні обмеження призвели до зниження соціального благополуччя найманих працівників багатьох галузей економіки. Попри доволі стабільну статистику зайнятості (табл. 3), стрімко зріс рівень прихованого безробіття, спричиненого вимушеними неоплачуваними відпустками персоналу через зупинку багатьох бізнес-напрямів (на піку карантинних обмежень 2020 р. воно сягало 17 \% або 3,1 млн осіб). Погіршення соціального становища відбулось також у понад 100 тис. трудових мігрантів, які змушені були повернутись в Україну, проте так і не змогли отримати достойної роботи.

Табл. 3. Рівень безробіття в Україні в 2020 р. (тис. осіб)

\begin{tabular}{|c|c|c|c|c|c|c|}
\hline Рік & $\begin{array}{c}\text { Всього насе- } \\
\text { лення }\end{array}$ & $\begin{array}{c}\text { Економічно активне на- } \\
\text { селення }\end{array}$ & $\begin{array}{c}\text { Зайняте насе- } \\
\text { лення }\end{array}$ & $\begin{array}{c}\text { Безробітне } \\
\text { населення }\end{array}$ & $\begin{array}{c}\text { Рівень безро- } \\
\text { біття, \% }\end{array}$ & $\begin{array}{c}\text { Зареєстрованих } \\
\text { безробітних }\end{array}$ \\
\hline 2016 & 42584,5 & 17303,6 & 15626,1 & 1677,5 & 9,7 & 407,2 \\
\hline 2017 & 42386,4 & 17193,2 & 15495,9 & 1697,3 & 9,9 & 352,5 \\
\hline 2018 & 42153,2 & 17296,2 & 15718,6 & 1577,6 & 9,1 & 341,7 \\
\hline I кв. 2020 & 41902,4 & 17381,8 & 15894,9 & 1486,9 & 8,6 & 338,2 \\
\hline II кв. 2020 & 4176,6 & 17329,9 & 15781,3 & 1548,6 & 8,9 & 349,4 \\
\hline III кв. 2020 & 41703,3 & 16992,1 & 15362,0 & 1630,1 & 9,6 & 517,7 \\
\hline IV кв. 2020 & 41588,4 & 16949,8 & 15306,8 & 1643,0 & 9,7 & 433,4 \\
\hline
\end{tabular}

Джерело: побудовано за [14].

Незважаючи на те, що у Фонді боротьби з Covid19 на 2020 р. на виплати матеріальної допомоги застрахованим особам, які можуть втратити доходи через тимчасову заборону їх сфери діяльності передбачалось понад 3,2 млрд грн, натомість реально використано тільки чверть цих коштів. Отож, у 2021 р. за умов посилення карантинних обмежень Кабінет Міністрів України планує відновити соціальну підтримку підприємців та найманих працівників.

\section{Висновки}

Недостатність нормативно-правового регулювання якості надання соціальних послуг в Україні ускладнює контроль за ефективністю видатків на соціальні заходи. Пандемія Covid-19 загострила соціальні ризики і спричинила до різкого зростання видатків бюджету на охорону здоров'я i соціальний захист населення попри зменшення фінансування окремих соціальних програм. Основними соціальними ризиками, пов'язаним з пандемією, є смерть значної частини українських громадян, інвалідізація чи довготривала втрата працездатності, значні матеріальні затрати на лікування, зростання рівня безробіття (у т.ч. прихованого) та погіршення соціально-економічного забезпечення працівників. Попри це, понад 37,23 \% сукупних видатків Фонду боротьби 3 Covid-19 мали нецільове спрямування, що значно обмежило інституційні можливості фінансової компенсації соціальних ризиків.

\section{References}

1. Boiko, A. O., \& Bozhenko, V. V. (2020). The impact of systemic risk on the dynamics of socio-economic development of the country. Economic Forum, 1(3), 23-30. https://doi.org/10.36910/6775-2308-8559-2020-3-4

2. Donnelly, R., \& Farina, M. P. (2021). How do state policies shape experiences of household income shocks and mental health during the Covid-19 pandemic? Social Science \& Medicine, 269. https://doi.org/10.1016/j.socscimed.2020.113557

3. He, H., \& Harris, L. (2020). The impact of Covid-19 pandemic on corporate social responsibility and marketing philosophy. Journal of Business Research, 116, $176 \quad-182$. https://doi.org/10.1016/i.jbusres.2020.05.030 
4. Lysiak, L., Kachula, S., \& Abdin, A. (2021). Budget policy in the field of expenditures in the coordinates of social development. World of Finance, 4(65), 39-55. https://doi.org/10.35774/sf2020.04.039

5. Mikhno, I. S., Koval, V. V., \& Navolokina, A. S. (2020). Social security risk management as a factor of sustainable development of industrial economy. Bulletin of Economic Science of Ukraine, 1, 148-153. https://doi.org/10.37405/1729-7206.2020.1(38).148-153

6. Ministry of Finance of Ukraine. (2021). Expenditures of the state budget of Ukraine. Retrieved from; https://index.minfin.com.ua/ua/finance/budget/gov/expense/2020/

7. Ministry of Finance of Ukraine. (2021). Unemployment rate in Ukraine. Retrieved from; https://index.minfin.com.ua/ua/labour/unemploy/

8. Pelishenko, I. I. (2020). Risk as a leading characteristic of modern society. Modern society: political sciences, sociological sciences, $\begin{array}{lll}\text { culturological } & \text { sciences, } & 1(20),\end{array}$ https://doi.org/10.34142/24130060.2020.20.1.14

9. Severo, E. A., Guimarães, J. C. F., \& Dellarmelin, M. L. (2021). Impact of the Sovid-19 pandemic on environmental awareness, sustainable consumption and social responsibility: Evidence from generations in Brazil and Portugal. Journal of Cleaner Production, 286. https://doi.org/10.1016/j.jclepro.2020.124947

10. Shevchenko, O. O., Minaieva, A. O., \& Lahutin, I. I. (2020). Institutions of social protection: reform as a factor in leveling social asymmetries. Tavriya Scientific Bulletin, 3, 123-129. https://doi.org/10.32851/2708-0366/2020.3.16
11. State Statistics Service of Ukraine. (2021). Demographic situation in January 2021. Retrieved from: http://www.ukrstat.gov.ua/express/expr2021/03/29.pdf

12. Svydruk, I. I. (2020). Creative approaches to the management of the development of the tourist industry in the conditions of a pandemic crisis. The economic discourse. International scientific journal, 4, 137-145. https://doi.org/10.36742/2410-0919-2020-4-14

13. Sydorkina, M. Yu. (2020). Social interest in the structure of competencies of democratic citizenship in the situation of the David19 pandemic. Scientific Studios on Social and Political Psychology, 46(49), 33-41. https://doi.org/10.33120/ssj.vi46(49).154

14. Vasylieva, T. A., \& Lieonov, S. V. (2020). Covid-19, SARS, H5N1, A / H1N1, EVD: a comparative analysis of the impact of pandemics on economic and social development in national, global and regional contexts. Scientific view: economics and management, 3(69), 24-28. https://doi.org/10.32836/2521-666X/2020-69-4

15. Verkhovna Rada Ukrainy. (2020). On Amendments to the Law of Ukraine "On the State Budget of Ukraine for 2020": Law of Ukraine № 553-IX of March 6, 2021. Retrieved from; https://zakon.rada.gov.ua/laws/show/553-IX\#Text

16. World Economic Forum. (2021). The Global Risks Report 2021. Retrieved from: http://wef.ch/risks2021

17. Yelisieiev, V. N., Bondarenko, O. O., \& Kovalov, O. S. (2019). On the issue of emergency risk management strategy. Scientific collection of the Institute of Public Administration in the field of civil protection, 7, 82 p. https://doi.org/10.35577/iducz.2019.07.07

\section{R. P. Pidlypna
Uzhhorod Trade and Economic Institute Kyiv National University of Trade and Economics, Uzhhorod, Ukraine \\ EXACERBATION OF SOCIAL RISKS IN UKRAINE IN THE CONTEXT OF THE COVID-19 PANDEMIC}

The paper deals with the issues considering social risks in Ukraine in the context of the Covid-19 pandemic. In the course of research we have revealed that the social sphere in Ukraine is characterized by a non-transparent system of providing social benefits, which leads to inefficient redistribution of resources to provide assistance to the poor. The dynamics of expenditures of the state budget of Ukraine indicates an increase in expenditures on social protection and health care and institutional support of citizens in a pandemic. At the same time, changes to the State Budget indicate the curtailment of certain socially significant programs. The planned social expenditures decreased generally, while the budget support of the Pension Fund increased. The creation of the Covid-19 AntiPandemic Fund provided financial support for the elimination of pandemic outbreaks, purchase of medical services, surcharges for physicians and other workers who provide livelihood of the population, financial assistance to citizens, and also transfers to the Pension Fund of Ukraine and the Social Insurance Fund. However, more than $37 \%$ of the funds were used for non-targeted funding of programs for the development and maintenance of public roads, development of high-achievement sports, the privatization of state property and the execution of court decisions against Ukraine. This has led to a lack of funds for the purchase of vaccines for immunization of the population, so in 2021 free vaccination is planned to cover only $20 \%$ of the population (physicians, military, citizens over the age of 60 , education workers). Given the pace of vaccination, the lack of contracted volumes and extremely high demand, Ukrainian citizens will have wide access to vaccines no earlier than 2022. Thus, the main social risks associated with the pandemic are the death of a significant number of Ukrainian citizens, short-term or long-term disability, significant material costs for treatment, rising unemployment (including hidden) and deteriorating socio-economic security of workers.

Keywords: death; short-term; long-term disability; unemployment; expenditures of the State budget. 